\title{
O diálogo entre ordem e desordem
}

No seu artigo introdutório o Professor Prigogine fala-nos de dupla revolução que se operou no pensamento científico no dealbar do século XX - uma revolução que não só alargou a natureza dos fenómenos conhecidos, como também o significado do próprio conhecimento.

No final do século XIX a física era um assunto encerrado onde pouco ou nada havia por descobrir. Os estudantes eram encorajados a demandar outras disciplinas, como a química, bastante mais promissoras. Lord Kelvin falava das duas únicas nuvens que ensombravam o edifício da física: o problema do éter e a radiação dos corpos quentes. Hoje sabe-se como essas duas "nuvens" arrastaram as tempestades da relatividade e da mecânica quântica. A partir da década de 90, com a descoberta dos raios XX (1895) e da radioactividade (1896), a física nunca mais seria a mesma.

Com as suas implicações cosmológicas a teoria da relatividade foi a primeira a captar a imaginação do grande público. A cabeleira revolta e o bigode farfalhudo de Einstein fizeram o resto. Embora mais intima, a revolução quântica não foi menos avassaladora. Durante os anos 20 assistiu-se a um emocionante diálogo entre Pauli e Bohr (com inevitáveis participaçð̃es especiais de matemáticos e físicos como Born, Heisenberg, Schrödinger e Dirac) numa tentativa (infrutífera) de conciliar o velho com o novo, o contínuo (teoria electromagnética) com o descontínuo (natureza discreta do electrão). A ultrarespeitada lei da conservação da energia quase se sumiu, engolida pelos ânimos exaltados dos físicos da época. O que desapareceu, de vez, foi a possibilidade de descrever uma situação física por uma imagem ou modelo visual, aquilo que os alemães ! tão arreigadamente clamavam ser um dos dons das ciências físicas (Anschaulichkeit). A mudança foi traumática pois "ver e crer como S. Tomás" é o credo do nosso processo cognitivo. Coleridge fora profético ao denunciar, mais de cem anos antes, o "despotismo da vista"'.

A física moderna trouxe outras alterações, entre elas a convicção einsteineana de que é a teoria que decide aquilo que podemos observar. $\mathrm{Na}$ teoria clássica, a interpretação física dos símbolos precede o formalismo matemático; na mecânica quântica o significado físico nasce da matemática. O Princípio da Incerteza de Heisenberg é a evidência final de que os conceitos de visualização e visuabilidade, que eram sinónimos em fisica clássica, se tornam incompatíveis na teoria quântica. Mutatis mutandis para a definição e observação.

As certezas deram lugar às dúvidas e às probabilidades, a concepção determinista foi abalada por componentes aleatórias, a irreversibilidade destruiu algumas simetrias sacrossantas. A permuta entre passado e futuro, que a mecânica clássica permitia, passa a ser comandada pela entropia que, para Eddington, era "a seta do tempo". Como afirma o Professor Prigogine, "o universo seleccionou, uma vez por todas (pelo menos assim parece) entre várias possibilidades, uma via particular". Já no princípio do século Einstein se tinha debruçado sobre a profunda asşimetria entre a carga negativa (electrão) e a carga positiva (protão), tão ao invés da simetria tempo-passado e tempo-futuro das cosmologias

Time present and time past

Are both perhaps present in time future,

And time future contained in time past.

If all time is eternally present

All time is unredeemald. 1

\section{T. S. Eliot, Four Quartets, 1935}

A grande questão, para Prigogine, é saber se existe um paradigma evolutivo comum aos fenómenos simples (físicos e químicos) e aos complexos (biológicos e sociais). E se é certo que foi o século XIX que nos deu as leis da evolução (com Lyell, Darwin, Clausius, Marx) que perturbantemente revelaram as analogias entre o físico e o social, competiu à teoria da relatividade, já no século XX, reformular o tempo, parâmetro por excelência de qualquer esquema evolutivo. É, afinal, a inserção do tempo na matéria que caracteriza a vida.

Para Lévy-Bruhl (citado por Prigogine) "'[a natureza] é ordem e razão, como o espírito que se debruça sobre ela". Tudo é construido à imagem e semelhança de tudo o resto. Talvez como consequência da simetria evolutiva que nos resta (dois olhos, dois braços, duas pernas) o homem pensa e associa por binários. É o “cru e o cozido" de Lévi-Strauss, mas são também o contínuo e o descontínuo, o dualismo onda-corpúsculo, os pares de variáveis conjugadas. A humanidade inteligente continua a fazer juízos de valor em termos de noções bem contrastadas, a preto e branco, em dialéctica \footnotetext{
Engineering, Cornell University, USA.

O tempo presente e o tempo passado

Estão ambos talvez presentes no tempo futuro,

E o tempo futuro contido no tempo passado.

Se todo o tempo é eternamente presente

Todo o tempo é irredimivel.
}

a Departamento de Engenharia Química, IST e School of Chemical

(T. S. Eliot, Quatro Quartetos, tradução de Maria Amélia Neto, Ática, Lisboa, 1983) 
constante. Cita-se, por exemplo, Starobinski para mostrar que virtualmente todos os domínios (das ciências físicas às ciências sociais, da criação artística aos debates políticos) fazem apelo às antinomias ordem-desordem, equilíbrio-desiquilíbrio, determinado-imprevisível. Sob outras roupagens, mais científicas, assiste-se à recriação das velhas lutas e tensões entre a rigidez do espírito clássico e a auto-destruição da sensibilidade romântica, deambulante por excelência.

Os filósofos políticos do século XIX sabiam que do caos e da decadência podia surgir o mundo novo; sobre as ruínas do passado construir-se-ia a "nova Jerusalém". A terceira revolução industrial trouxe também consigo uma nova compreensão e utilização do caos aleatório e do ruído. Descobrem-se mecanismos novos que permitem aos sistemas reorganizarem-se, passarem de um estado de consciência individual a um estado coerente e colectivo. É a vida que emerge, triunfante, do caldo caótico; é a "raiva pela ordem", de que falava Wallace Stevens, a vingar.

Os artigos dos Professores Nicolis e Van Den Broecke explicam-nos estes mecanismos novos de bifurcação e de comunicação de longo alcance. Na ciência, tal como nos negócios humanos, tudo se ramifica, mas tudo se parece cada vez mais com tudo o resto. As últimas novidades indicam que tudo no universo, desde os “quarks" ao DNA, é feito de fios e não de partículas (“'superstring”).

Para o cientista o aleatório e o indeterminismo caracterizam a natureza do nosso conhecimento; para o artista o interesse é predominantemente estético. Não é por acaso que o uso sistemático da "collage" e do aleatório como método artístico criador coincidiu com a revolução informática. Mallarmé esticou a língua francesa até aos limites possíveis da sintaxe, mas foi Butor quem escreveu (ou colou) Mobile (1962). Burroughs deixou-nos a receita que seguiu na feitura de The Exterminators (1960): "pega numa página mais ou menos da tua autoria ou de qualquer escritor vivo ou morto. Corta-a em secções usando tesoura ou navalha de barbear, conforme o gosto, e rearranja as secções, olhando para o lado. Agora escreve e passa a limpo o resultado"'. Rauschenberg andou pelas praias de Staten Island, as lojas de ferro-velho da Canal St. e as sarjetas da baixa nova-iorquina à procura de objectos para as suas colagens. Stockhausen incorporou os sons da sua respiração e os nomes das amantes na composição em grande escala, Hymnen. Pollock saltava para cima das telas e salpicava tudo à sua volta com uma brocha a escorrer em tinta. $\mathrm{O}$ resultado disto tudo pode-se encontrar em bibliotecas, museus e salas de concerto e partilha, com as obras de arte clássicas do passado, a capacidade de nos perturbar e divertir. A ordem espreita, a cada passo, no emaranhado do aleatório.

\section{A. A violent order is disorder; and} B. A great disorder is an order. These two things are one.

\section{Wallace Stevens, Connoisseur of chaos} (Parts of a World, 1942)

O diálogo de opostos não passa, afinal, de mais um exercício em narcisismo.

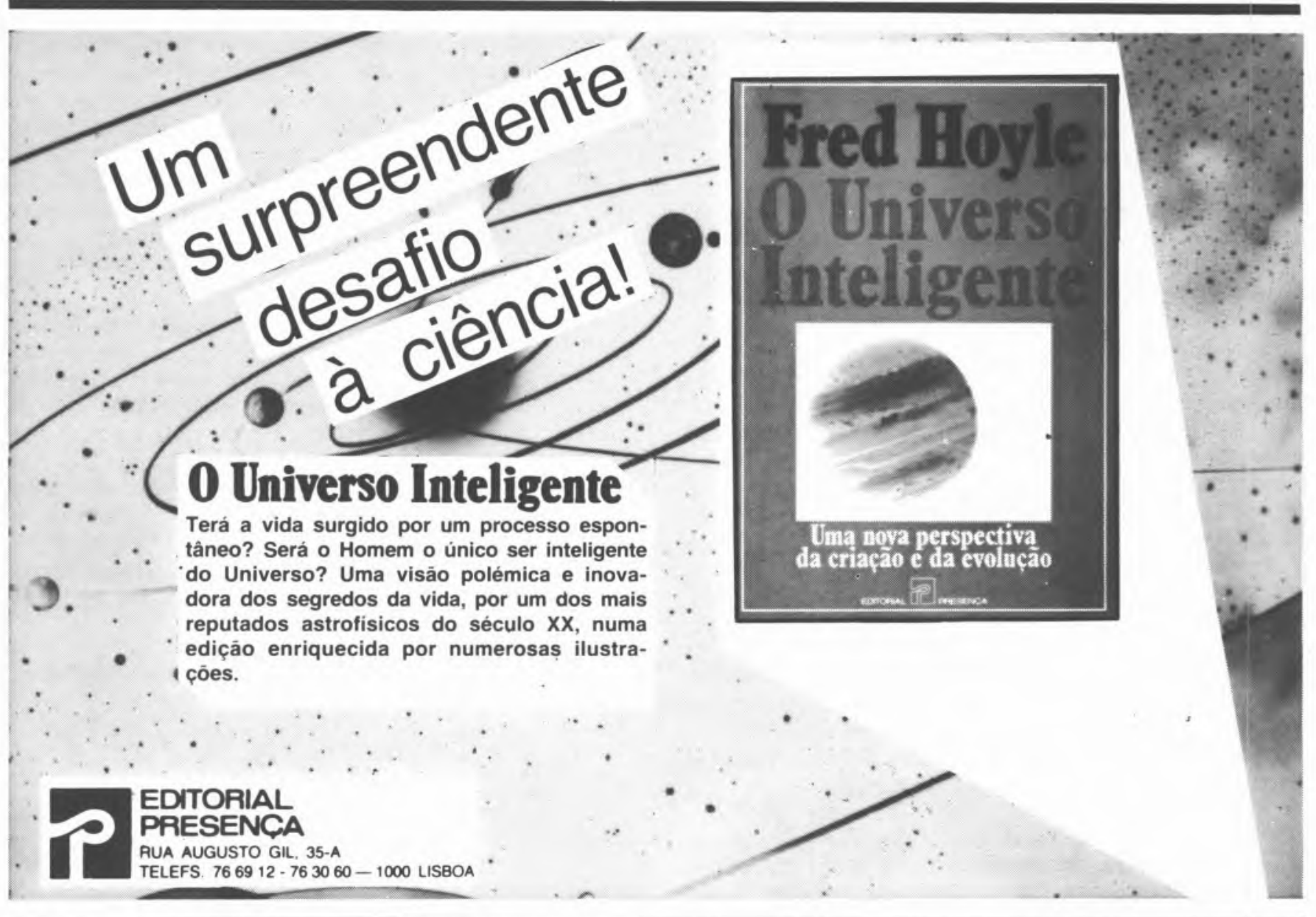

